another new Gymnospermous group, the Jurassic Pentoxyleæ, in which naked seeds with fleshy integuments are clustered directly on to a cauline cone axis totally devoid of any trace of leaf-like appendages, provides a wholesome corrective against the hasty generalizations which Calathospermum by itself might arouse in the unwary. Both Calatho. spermum and the Pentoxyleæ are, however, of first-rate theoretical importance in the phylogeny of the Gymnosperms, and both, therefore, merit the attention of a general botanist.

${ }^{1}$ Walton, J., "Introduction to the Study of Fossil Plants" (London. 1940).

'Gordon, W. T., Trans. Roy. Soc. Edin., 60, 427 (1941).

'Andrews, H. N., Bot. Gaz., 110, 13 (1948).

'Sahni, B., Bot. Gaz., 110, 47 (1948).

1016

\section{EUROPEAN CORN BORER IN NORTH AMERICA}

$\mathrm{T}$ HE European Aprn breer (Pyrausta nubilalis) was first found in the United States in 1917, among swegt coln ndar Boston, Mass., where it was infegting affarea of at least 100 square miles. It was later aund that the insect was also present at the same time near St. Thomas, Ontario. The actual date or year of entry of this dangerous pest into North America is uncertain, but circumstantial evidence points to its occurrence among broom-corn imported from Hungary or Italy between 1909 and 1914.

The insect is among the most threatening of all pests of Indian corn (or maize) ; accumulated knowledge shows that its eradication is not possible, but various cultural practices can be adopted so that there results a reduction in the losses caused by the insect. According to W. A. Baker and W. G. Bradley, entomologists of the U.S. Bureau of Entomology and Plant Quarantine, the damage caused by the borer in the United States in 1945 was estimated at $36,700,000$ dollars. In a recent publication by these two entomologists* they state that infested areas extend all down the east coast and across the continent to districts west of the Great Lakes. The favourite plant host in America, as in Europe, is Indian corn (maize), but the insect also attacks beans, soybean, millet, oats, potatoes and some other cultivated crops. Garden flowers are also infested, notably dahlias, gladioli, zinnias, chrysanthemums and various weeds that grow among or bordering the maize crop. Among the Lakes States the corn borer is single-brooded and feeds almost entirely on maize, whereas in the southern and eastern parts of the infested region two or even three broods prevail, and the insects affect a wide range of different plants. The injuries it causes are effected during the larval stages when it tunnels into the stalk, main stem or mid-rib of its host-plant, as the case may be. As a result of the damage thus caused, much of the nutriment is cut off from the ear or flowering part, which weakens or flags and breaks.

As regards methods of controlling the borer, the indigenous insect parasites have proved of no avail. They number twenty-four different species, yet their combined activities have resulted in the destruction

* U.S. Department of Agriculture. Farmers' Bulletin No. 1548 : The European Corn Borer; its Present Status and Methods of Con trol. Revised edition, by W. A. Baker and W. G. Bradley. Pp. 46. (Washington, D.C.: Government Printing Office, 1948.) 15 cents. of only a fraction of 1 per cent of the borer. Large numbers of foreign parasites have been introduced from Europe and have established themselves, but it is premature to state whether they will prove to be effective controlling agents. At the present time the corn borer can be best controlled by utilizing or destroying all parts of infested plants before any of the insects they may contain are able to change into the adult or moth stage. Feeding affected crops to livestock either directly from the field or as silage is a valuable method. In other cases deep ploughing beneath the soil or complete burning of all infested vegetation before the spring when the moths appear is recommended. Any method that leaves behind living borer caterpillars among the plant residues merely provides for the infestation to go on during the following year. The use of insecticidal sprays containing D.D.T. or other toxic agents has been recommended for use during the period when the eggs are hatching, in order to destroy the young caterpillars.

\section{6 \\ FORTHCOMING EVENTS \\ (Meetings marked with an asterisk * are open to the public) \\ Monday, May 9 \\ RoYaI, GEOGRAPH aA, SOCIETY (at Kensington Gore, London, S.W.7), at $5 \mathrm{~mm}$. - cre S. W. Wooldridge and Mr. S. H. Beaver "Land Ise d d iculace Mineral Working in Pritain". UN URSIT
Colle "Aspects of Biological Discovery, 2, Circulation of the Blood"." \\ INSTTTUTION OF FIECTRICAL ENGINEERS, EDUCATION DISCUSSION CIRCLE (at Savoy Place, Victoria Embankment, London, W.C.2), a 6 p.m.-Discussion on "Graphical Methods in Teaching Electrica} Engineering (including Radio)" (to be opened by Mr. S. N. Ray).

\section{Tuesday, May 10}

RoYal ANTHRopological INSTituty (at 21 Bedford Square, ROYAL ANTHROPOLOGICAL INSTITUTK (at 21 Bedford Square, London, W.C.1), at 5 p.m.-.

UNIVERSITY OF LONDON (at the London School of Economics and Political Science, Houghton Street, Aldwych, London, W.C.2), a 5 p.m.- Prof. D. V. Glass : "The Application of Social Research" (Inaugural Lecture).*

Zoological SOCIETy OF LONDON (at the Zoological Gardens, Regent's Park, London, N.W.8), at 5 p.m.-Scientifte Papers.

SOCIETY OF ChEMICAL INDUSTRY, CheMICAL ENGINGERING GROUP (at the Geological Society, Burlington House, Piccadilly, London, W.1), at $5.30 \mathrm{p.m}$.-Mr. W. Barr and Mr. J. Frskine: "Tine Manufacture and Use of Stainless-Clad Steel".

UNIVERSITY OF LONDON (at the London School of Hygiene and Tropical Medicine, Keppel Street, London, W.C.1), at 5.30 p.m.Prof. Jacques Tréfouẻl (Paris): "Some Advances in Chemotherapeutic Research at the Pasteur Institute"."

ILLUMINATING ENGINERRING SocieTr (at the Royal Society of Arts, John Adam Strot, General Meeting; at 6.30 p.m.-An Address by Monsieur L. Gaymard.

Wednesday, May II

INSTITUTE OF FUel, NORTH-WESTRRN SECTION (at the Engineers' Club Albert Square, Manchester), at 11 a.m.-Conference on "Combined Heat and Power Supplies".

GEOLOGICAL SOCIETY OF LONDON (at Burlington House, Piccadilly, London, W.1), at 5 p.m.-Dr. Robert Broom, F.R.S.: "South Africa's Contribution to our Knowledge of Man's Evolution;"

UNIVRRSITIES FEDERATION FOR ANIMAL WRLFARE (in the Anatomy Theatre, University College, Gower Street, London, W.C.1), at 5.15 p.m.-Dr. Jean-Paul Harroy: "Nature Protection".

Institute of PeTroleum (at Manson House, 26 Portland Place. London, W.1), at 5.30 p.m.-Mr. F. Morton: "Examination of Crude Oils in relation to Geological Formations".

Physical Sochety, Low Temperature Group (in the Lecture Theatre, Science Museum, Exhibition Road, London, S.W.7), at 5.30 . - Discussion on "The Use of Thermodynamic Diagrams in Industry" (to be opened by Prof. D. M. Newitt, F.R.S.).

ROYAL Institution (at 21 Albemarle Street, London, W.1), at 9 p.m.-Prof. E. K. Rideal, F.R.S. : "How Crystals Grow".

Thursday, May 12

Council for the Preservation of Rural England (at the Royal Institute of British Architect3, 66 Portland Place, London, W.1), at 2.30 p.m. - Annual General Meeting.

RoYal Society (at Burlington House, Piccadilly, London, W.1) at 4.30 p.m.-Prof. H. Raistrick, F.R.S. : "A Region of Biosynthesis" (Bakerian Lecture) 